\title{
Quality of Life among Caregivers of Persons Living with Sickle Cell Anemia: The Influence of Psychosocial Factors
}

\author{
Obosi AC* and Izedomi E Lydia \\ University of Ibadan, Oyo state, Nigeria
}

Submission: October 26, 2018; Published: December 06, 2018

*Corresponding author: Obosi AC, University of Ibadan, Oyo state, Nigeria

\begin{abstract}
Patients and caregivers of patients with sickle cell disease may experience physical and psychological dysfunction in their daily lives. These dysfunctions are not unconnected with the distressing symptoms associated with providing care for the wards. Although several studies have revealed the distress and outcome in terms of reduced quality of life experienced by the persons living with the condition themselves, there appears to be a dearth of research on the role of some psychological and social factors on the quality of life of the care givers. It is against this background that this study examined the influence of psychological capital (hope, resilience, optimism \& self-efficacy) on the quality of life of caregivers of persons living with sickle cell anemia in Lagos state, Nigeria. Using a cross-sectional survey design, data were collected from 101 caregivers of sickle cell patients in Lagos state using a convenient sampling technique, (males $=57$, females $=44$ ) with a mean age of 34.43 years.

The results showed that there was a significant sex difference in the quality of life experienced by the caregivers, with males reporting higher quality of life than females $(t=2.040 ; \mathrm{df}=99 ; \mathrm{p}<.05)$. The results further showed that psychological capital of hope $(\beta=-.279 ; \mathrm{t}=-2.527$; $\mathrm{P}=<.05)$ and optimism $(\beta=-.260 ; \mathrm{t}=-2.472 ; \mathrm{P}=<.05)$ significantly predicted quality of life independently, while resilience and self-efficacy did not significantly predict quality of life. Lastly it was observed that caregivers from monogamous families reported significantly higher quality of life than their counterparts from polygamous families $(t=2.040 ; \mathrm{df}=99 ; \mathrm{p}<.05)$. The results therefore recommended that interventions to boost the quality of life of caregivers of sickle cell patients' should target creating a new life orientation in terms of having an optimistic approach to life no matter the condition alongside refusing to give up hope. Also, it was recommended that attention should focus on female caregivers and caregivers from polygamous families with the aim of improving their quality of life.
\end{abstract}

Keywords: Quality of Life; Sickle cell anemia; Psychosocial factors

\section{Introduction}

Sickle cell disease affects approximately 100,000 Americans and has been established to affects about 1 out of every 365 Blacks or African-American birth, about 1 in 13 Black or African-American babies is born with sickle cell trait (SCT) (WHO, 2014). Sickle cell disease is a genetic blood disorder that affects the haemoglobin within the red blood cells and has been found to cause death among Blacks or African-American children, younger than 4 years of age which fell by 42\% from 1999 through 2002 (WHO 2014), this significant drop was because of the advent of vaccine in 2000 that protects against invasive pneumococcal illness in individuals (WHO 2014). Sickle cell has not been given adequate recognition by the Nigerian Government in recent time, despite several nongovernmental organizations creating awareness of this illness (Nigerian Medical Association, 2015).

There are insufficient studies out on psychological factors influencing quality of life in patients and caregivers of patients living with sickle cell disease [1]. Most previous studies on the quality of life of sickle cell patients have neglected the quality of life of the caregivers of these patients [2,3]. The sickle cell disease has a significant implication for the physical and psychological wellbeing among affected individuals; as a result, psychological capitals including self-efficacy, optimism, hope and resilience has been indicated to be importance on the quality of life among people living with sickle cell disease [2].

The concept of quality of life is a multidimensional concept that has called for attention recently from the researchers. Quality of life is the satisfaction of needs that are determined by the perceived discrepancy between one's aspiration and achievements [4]. From the definition, the higher the satisfaction experienced with life, the higher the quality of life among individuals and vice versa. The quality of life in an individual's experience is critical in determining their overall health and wellbeing, and hence, imperative to focus on unravelling psychological capitals influencing of quality of life among individuals. It is also essential 
to understand the quality of life of sickle cell patients because there should be new approach aside from the medical approach to understanding this quality of life. [2] reported that besides merely pharmacotherapy, restoration of overall quality of life should be the mainstay of management of patients with sickle cell disease, as well as their caregivers or significant others.

In another study, Barakat, et al. [5] found that physical and psychological functioning significantly diminished in patients of sickle cell disease. Similarly, Ayinmode [6] reported a psychosocial dysfunction in children and caregivers of persons living with sickle cell disease, the psychosocial decline included tension and anxiety among patients' family. This reflects that apart from patients of sickle cell disease, even the quality of life of their caregivers can be affected, as such, quality of life should be given attention to in every treatment process, formulating treatment plans for patients with terminal illness, interventions should aim at improving the quality of life should also be incorporated into the treatment plans. The quest to understand the reasons for the poor quality of life experienced by patients with terminal illness and their caregivers is what informed this current study.

Moreover, Bentsen [7] examined self-efficacy as a predictor of improvement of health status and overall quality of life, results showed that self-efficacy predicted both improvement of health status and overall quality of life. Also, Cramm [8] reported that general self-efficacy influenced the quality of life of patients with multiple sclerosis. Similarly, Haugland [9] examined the association between self-efficacy and social-support on the quality of life of cancer patients and caregivers, and findings showed that self-efficacy influenced the quality of life of cancer patients and caregivers. These findings from literature therefore suggest the need to examine more roles self-efficacy play in the overall physical and psychological wellbeing of individuals.

Furthermore, optimism as another concept of psychological capital affiliated with positive potentials within individuals, having a positive feeling about life is essential in facilitating recovery from ill health and in maintaining a good health. In Mazanec [10], it was reported that patients who had positive feelings about their lives were willing to adopt healthy lifestyle to keep them healthy after diagnosed with cancer. Additionally, Conversano [11] documented optimism and its impact on mental and physical wellbeing and reported that optimism had significant impacts on overall mental and physical wellbeing. Equally, in Vilhena's [12] study among Portuguese patients diagnosed with chronic disease, it was reported that optimism played a significant role in the quality of life experienced.

Among Chinese sample, optimism showed a significant influence on quality of life among cancer patients [13,14], optimism contributed significantly to the quality of life in family caregivers. This suggests a new dimension for approaching chronic disease among patients and its impact on the family and their caregivers. In addition, Jafari [15] reported that hope which is positive emotions in cancer patients enhanced their adherence to medications and recovery. Likewise, hope as a psychological factor affects quality of life in patients with psoriasis [16] and played a significant role in the quality of life experienced in the family [17].

In the same way, resilience as the process of adapting well in the face of adversity, trauma, tragedy, threats, or significant sources of stress (American Psychological Association, 2014), has been found to significantly determines quality of life [18], positively associated with quality of life among Chinese cancer patients and their families Li, Yang, Liu \& Wang, 2016. Resilience significantly predict quality of life among Pakistan outpatients with heart disease [19], caregivers of patients with posttraumatic stress disorder [20], among dementia caregivers in Latin America [21] resilience and demographic information was also found to significantly influence quality of life among caregivers in Iranian sample [22], with males reported significant higher quality of life compare with females [23].

Following the above literature review on psychological capital (hope, resilience, self-efficacy and optimism) as a predictor of quality of life, numerous gaps have being identified from literature such fewer or no published studies has been done on the influence of psychological capital (self-efficacy, hope, resilience and optimism) on quality of life using Nigerian sample, this propel the researcher to further embark on this present study and thus form a platform upon which this current study can continue from. This study would provide a pathway for understanding the quality of life experienced by caregivers of patients with sickle cell disease. Findings from this study would form the bedrock for the psycho-education of caregivers of sickle cell disease patients. This study would also enlighten healthcare professionals in managing patients with sickle cell disease. As a result of this study, caregivers of sickle cell disease patients would be included in the treatment approach.

Hence, the following research questions were derived from the literature review and on the focus of this current study would be answered: Are there gender differences in the quality of life reported among caregivers of sickle cell patients? Do selfefficacy, optimism, resilience and hope have significant joint and independent influence on quality of life among caregivers of sickle cell patients? Do socio-demographic information (age, religion, educational level, and marital status) have significant joint and independent influence on quality of life among caregivers of sickle cell patients? The purpose of this study would be to answer the aforementioned research question. In doing this, following hypotheses were formulated and tested:

a) Self-efficacy, optimism, resilience and hope will have a significant joint and independent influence on quality of life among caregivers of sickle cell patients.

b) Socio-demographic information (age, ethnicity, religion, family background, educational level, and family size) will have a significant joint and independent influence on quality of life among caregivers of sickle cell patients. 
c) Male caregivers will be higher on quality of life than their female counterparts.

d) Caregivers from monogamous background will be higher on Quality of Life than their polygamous counterpart.

Methods

\section{d.1. Design}

A Survey Cross-sectional research design and a purposive sampling technique was adopted in this study, because the researcher aimed investigate the influence of psychological capital (hope, resilience, self-efficacy and optimism) on quality of life among caregivers of sickle cell patients.

\section{d.2. Setting}

The study was carried out in two different private hospitals in Lagos state, Oshodi-isolo local governmentarea namely G.O Private Hospital Ikeja and Pinecrest Private Hospital Mafoluku, airport road Oshodi Lagos. These hospitals are government approved primary health care centres that provide general medical services to their clients. They also provided specialized services in the area of sickle cell anemia for persons with the condition.

\section{d.3. Participants}

A total of 101 participants were involved in the study. Participants age ranged between 18 and 56 with a mean of $(\mathrm{x}=$ 34.3; SD = 8.5). On gender, $44(43.6 \%)$ of the participants were males, 57 (56.4\%) were females. On religion, 58 (57.4\%) were christians, 40 (39.6\%) were Muslims, and $3(3 \%)$ belong to the traditional religion. On ethnicity, $35(34.7 \%)$ were of the Igbo extraction, 23 (22.8) were Yorubas, 6 (5.9\%) were Hausa, and the remaining 37 (36.6\%) belong to other tribes. On educational qualification, $10(9.9 \%)$ were primary school certificate holders, 26 (25.7\%) were SSCE certificate holders, 57 (56.4\%) were B.Sc/ HND/NCE certificate holders, and 7 (6.9\%) were M.Sc certificate holder, and 1 (1\%) holds Ph.D certicicate. On family structure, 59 (58.4\%) came from a monoganous background, and 42 (41.6\%) came from a polygamous background. On family size, 28 (27.7\%) belong to one family size background, $14(13.9 \%)$ belong to two family size background, $16(15.8 \%)$ belong to three family size background, $20(19.8 \%)$ belong to four family size background, $11(10.9 \%)$ belong to five family size background, and $12(11.9 \%)$ belong to six family size background. Only caregivers of patients living with sickle cell anemia participated in the study.

\section{Research Instruments}

A structured questionnaire was adopted in this study which comprised six sections:

Section A: Demographic profile of the participants which are gender, age, religion, family background, educational level, marital status, ethnicity and family size.

\section{Section B}

Hope Scale: The adult trait hope scale by Snyder, Harris, Anderson, Holleran, Irving, Sigmon, Yoshinobu, Gibb, Langelle, and Harney [24] was used to measure the hope level of the participants in this study. The scale consists of 12 items and was on 8-point likert response format. High scores indicated high hope, while low scores indicated low hope. Snyder et al. [24] reported a good internal consistency of 0.88 for the scale using Cronbach's alpha, while in this study, Cronbach's alpha of 0.98 was established.

\section{Section C}

Resilience scale: The resilience scale developed by [25] was adopted to measure resilience of the participants. The scale consisted of 12 items and was on a 5-point Likert response format. High scores meant high resilience while low scores meant low resilience. Nicholson reported a good internal consistency of 0.75 for the scale using Cronbach's alpha. In this study, Cronbach's alpha of 0.87 was derived.

\section{Section D}

Self-efficacy scale: The general self-efficacy scale developed by Schwarzer and Jerusalem (1995) was used to measure the selfefficacy level of participants. The scale consisted 10 items and was on a 4-point Likert response format. High scores meant high self-efficacy and low scores meant low self-efficacy. The author reported a good internal consistency of 0.92 for the scale using Cronbach's alpha, while 0.95 was reported in this study.

\section{Section E}

Optimism scale: The optimism scale developed by Scheler and Carver (1985) was used to measure the optimism level of participants. The scale consisted of 10 items and was on a 5-point likert response format. High scores meant high optimism and low scores meant low optimism. Scheler and Carver (1985) reported a good internal consistency of 0.83 for the scale using Cronbach's alpha and 0.80 Cronbach's alpha was found in this study.

\section{Section F}

Quality of Life Scale: The SF-12, a multipurpose short form survey with 12 questions, all selected from the SF-36 health survey developed by Ware, Kosinski, and Keller (1996) was used to measure the quality of life of participants. The scale provided a glimpse into the mental and physical functioning and health related quality of life by asking participants to indicate their extent of satisfaction with different areas of their lives. Ware, Kosinski, and Keller (1996) reported a reliability of 0.92 using Cronbach's alpha. In this study, 0.85 Cronbach's alpha was reported.

\section{Procedure}

Upon the arrival of the researcher to the research setting, the letter of introduction and research proposal were presented to the hospital management seeking permission to undertake the study. Approval was granted after two weeks by the hospital management. Participant for the study were selected using accidental sampling technique. Selected participants from the research settings were informed on the research purpose of the study in order to gain their informed consent and enabling atmosphere for administration of the questionnaire. Participants 


\section{Psychology and Behavioral Science International Journal}

were also instructed on how to respond to the questionnaire and then given a copy to respond to. After two weeks of administration, 101 questionnaires were satisfactorily filled and were collated for statistical analysis.

\section{Statistical Analysis}

Data collected in the study were analysed using Statistical Packages for Social Sciences (SPSS) version 20. Multiple regression analysis was used for hypothesis one and two, while independent sample t-test analysis was used for hypothesis three and four.

\section{Results}

The results where is presented in line with the stated hypothesis. Hypothesis one stated that there will be significant joint and individual influence of hope, self-efficacy, resilience, and optimism on quality of Life among caregivers of sickle cell patients. This hypothesis was tested using multiple regression analysis. Table 1 presents the results.

Table 1: Summary table of multiple regression analysis showing the prediction of hope, self-efficacy, resilience, and optimism on quality of Life among caregivers of sickle cell patients.

\begin{tabular}{|c|c|c|c|c|c|c|c|}
\hline Variables & $\mathbf{R}$ & $\mathbf{R}^{2}$ & $\mathbf{F}$ & $\mathbf{P}$ & $\boldsymbol{\beta}$ & $\mathbf{t}$ & $\mathbf{S i g}$ \\
\hline Hope & & & & & -0.279 & -2.527 & $\mathrm{p}<.05$ \\
\hline Resilience & 0.334 & 0.111 & 3.007 & $\mathrm{p}<.05$ & 0.001 & 0.011 & $\mathrm{p}>.05$ \\
\hline $\begin{array}{c}\text { Self-Effi- } \\
\text { cacy }\end{array}$ & & & & & -0.077 & -0.708 & $\mathrm{p}>05$ \\
\hline Optimism & & & & & -0.26 & -2.472 & $\mathrm{p}<.05$ \\
\hline
\end{tabular}

Table 1 showed that there was a significant joint influence of hope, self-efficacy, resilience, and optimism on quality of Life of sickle cell caregivers $\left(\mathrm{R}^{2}=.111, \mathrm{~F}(4,96)=3.007, \mathrm{p}<.05\right)$ with $11.1 \%$ explanation of the variability on the quality of life. Hope $(\beta=-.279 ; \mathrm{t}=-2.527 ; \mathrm{P}<.05)$ and optimism $(\beta=-.260 ; \mathrm{t}=-2.472$; $\mathrm{P}<.05$ ) had a significant independent prediction on quality of life of sickle cell caregivers. That is, per unit change in hope of the caregiver showed about $27.9 \%$ impact on their quality of life and also, per unit change in optimism showed an amount $26 \%$ impact on quality of life of caregivers living of sickle cell patients. However, resilience $(\beta=.001 ; t=.011 ; P=>.05)$ and self effiecacy $(\beta=-.077 ; t=-.708 ; P>.05)$ did not independently predict quality of life. Therefore, hypothesis one is partially confirmed. The second hypothesis stated that socio-demographic information (age, ethnicity, religion, family background, educational level, and family size) will jointly and individually predict quality of life among caregivers of sickle cell patients. This hypothesis was tested using multiple regression analysis. Table 2 presents the results.

Table 2 showed that there was a significant joint influence of age, educational level, religion, and family size on quality of life of sickle cell caregivers $\left(\mathrm{R}^{2}=.092, \mathrm{~F}(4,96)=2.440, \mathrm{p}<.05\right)$ with $9.2 \%$ explanation of the variability on their quality of life. Also, religion $(\beta=-.199 ; t=-1.982 ; \mathrm{P}=<.05)$ and family size $(\beta=.233$; $\mathrm{t}=2.354 ; \mathrm{P}=<.05)$ had a significant independent influence on quality of life of sickle cell caregivers. However, age $(\beta=-.101$; $\mathrm{t}=-1.022 ; \mathrm{P}>.05)$ educational level $(\beta=-.028 ; \mathrm{t}=-.288 ; \mathrm{P}>.05)$ did not independently predict quality of life of sickle cell caregivers. Therefore, hypothesis two is particially accepted.

Table 2: Summary table of multiple regression analysis showing the prediction of socio-demographic information (age, ethnicity, religion, family background, educational level, and family size) will jointly and individually predict Quality of Life among caregivers of sickle cell patients.

\begin{tabular}{|c|c|c|c|c|c|c|c|}
\hline Variables & $\mathbf{R}$ & $\mathbf{R}^{2}$ & $\mathbf{F}$ & $\mathbf{P}$ & $\beta$ & $\mathbf{T}$ & Sig \\
\hline Age & & & & & -0.101 & -1.022 & $\mathrm{p}>.05$ \\
\hline $\begin{array}{c}\text { Education- } \\
\text { al Level }\end{array}$ & & & & & -0.028 & -0.288 & $\mathrm{p}>.05$ \\
\hline Religion & 0.304 & 0.092 & 2.44 & $\mathrm{P}<.05$ & -0.199 & -1.982 & $\mathrm{p}<.05$ \\
\hline Family size & & & & & 0.233 & 2.354 & $\mathrm{p}<.05$ \\
\hline
\end{tabular}

Hypothesis three stated that male caregivers will be higher on quality of life than their female counterpart. This hypothesis was tested using t-test of independent analysis. Table 3 presents the results from table 3 showed that there was a significant difference between male caregivers and female caregivers on quality of life $(\mathrm{t}=2.040 ; \mathrm{df}=99 ; \mathrm{p}<.05)$. A further observation of means however reveals that male caregivers $(=32.2 ; \mathrm{SD}=5.4)$ reported better quality of life than female caregivers $(=30.1 ; \mathrm{SD}=4.9)$. Consequently, hypothesis one is confirmed.

Table 3: Summary showing the difference between male and female caregivers on quality of life.

\begin{tabular}{|c|c|c|c|c|c|c|}
\hline $\begin{array}{c}\text { Gender of the } \\
\text { Caregivers }\end{array}$ & N & Mean & SD & df & T & Sig \\
\hline Male & 44 & 32.2 & 5.4 & 99 & 2.04 & $\mathrm{p}<.05$ \\
\hline Female & 57 & 30.1 & 4.9 & & & \\
\hline
\end{tabular}

Additionally, hypothesis four stated that caregivers from monogamous background will be higher on Quality of Life than their polygamous counterpart. This hypothesis was tested using t-test of independent analysis. Table 4 presents the results. Results from table 4 showed that there was a significant difference between caregivers from monogamous background and caregivers from polygamous background on quality of life $(\mathrm{t}=$ 2.040; $\mathrm{df}=99 ; \mathrm{p}<.05$ ). A further observation of means however reveal that caregivers from monogamous family background (=31.9; $\mathrm{SD}=5.4$ ) reported better quality of life than female caregivers from polygamous family background $(=29.8 ; \mathrm{SD}=4.7)$. Therefore, hypothesis four is confirmed.

Table 4: Summary showing the difference between caregivers from monogamous background and caregivers from polygamous background on Quality of Life.

\begin{tabular}{|c|c|c|c|c|c|c|}
\hline Family background & N & Mean & SD & df & T & Sig \\
\hline Monogamous & 59 & 31.9 & 5.4 & 99 & 2.04 & $\mathrm{p}<.05$ \\
\hline Polygamous & 42 & 29.8 & 4.7 & & & \\
\hline
\end{tabular}

\section{Discussion}

This study examined the influence of psychological capital on quality of life among caregivers of persons living with sickle cell anemia. Four hypotheses were formulated and tested; two were partially supported and two were fully confirmed. The first hypothesis was partially supported as hope and optimism independently contributed to the influence and prediction of 
sickle cell caregivers' quality of life while resilience and selfefficacy did not independent influence quality of life among sickle cell caregivers. However, the there was a joint influence of psychological capital (hope, resilience, self-efficacy and optimism) on quality of life among sickle cell caregivers. These findings indicated that psychological capital (hope, resilience, self-efficacy and optimism) importantly contributed to the quality of life of sickle cell caregivers this supported the findings of $[2,13,14,26]$ that psychological capitals including self-efficacy, optimism, hope and resilience has been indicated to be importance and influencing factors on the quality of life among people living with sickle cell disease and their caregivers.

Specifically, hope independently influence quality of life of caregivers of person with sickle cell. This result consistent with [15] who reported that hope enhanced adherence to medications, recovery and quality of life, also in line with the findings of $[16,17]$ that hope as a psychological factor affects quality of life and played a significant role in the quality of life experienced in the family of person's living sickle cell. Additionally, optimism contributed to the quality of life of sickle cell caregivers, better optimistic indicates quality of life of the caregivers.

This outcome confirmed Conversano (2010)'s study conclusion that optimism significantly impacts mental and physical wellbeing, similarly, the results consistent with $[13,14]$, that optimism contributed significantly to the quality of life in family caregivers. Thus, the non-independent significant of selfefficacy and resilience on quality of life negated the findings of [19] who reported significant independent influence of self-efficacy and resilience on quality of life. This invariance may be as result of that these factors (self-efficacy and resilience) tends toward individual characteristics which differs from one individual to another, and this may some consequences and implications regarding their quality of life.

Furthermore, the second hypothesis was also partly supported; the findings showed that religion and family size independently predict quality of life and religion, family size, age, and educational level jointly predict quality of life among caregivers of sickle cell patients. This finding supported [22] who discovered that socio-demographic information was also found to significantly influence quality of life among caregivers.

Similarly, hypothesis three was confirmed as gender differences significantly influence quality of life with male caregivers' significantly better in their quality of life than female caregivers. This result supported Rosenberg et al. [23] findings who discovered that male caregivers significantly scored on quality of life than female caregivers. Moreover, fourth hypothesis was fully supported as caregivers from monogamous background significantly higher on quality of life than their polygamous counterpart. The findings consistent with [22] study outcome that who discovered that socio-demographic information including differences including family background significantly influence quality of life among caregiver's family.

\section{Conclusion}

This study examined the influence of psychological capital on quality of life among caregivers of persons living with sickle cell anemia. Four hypotheses were formulated and tested; two were partially supported and two were fully confirmed. This study established that hope, self-efficacy, resilience, and optimism jointly influence quality of Life among caregivers of sickle cell patients; and specially, optimism and hope independently influence quality of life while self-efficacy and resilience did not independently influence quality of life among caregivers of sickle cell patients [27-30]. Also, socio-demographic profile (age, ethnicity, religion, family background, educational level, and family size) jointly while religion and family size independently predict quality of life among caregivers of sickle cell patients. Additionally, gender differences significantly contributed to quality of life, while male caregivers significantly higher on quality of life than female caregivers of sickle cell patients. Moreover, family background of the caregiver significantly important on their quality of life, with caregivers form monogamous family background significantly better on quality of life than care givers form polygamous family [31-40].

\section{Implication of Findings}

One implication of this study is that Nigerian society emphasizes gender roles, these different roles might contribute to the quality of life experienced by the different gender, and therefore gender of caregivers may be an important consideration when trying to improve the quality of life of caregivers. Another implication from this study is that, socio-demographic factors such as religion and family background, family size significantly influence quality of life of caregivers of persons living with sickle cell disease [41-45]. This means that religious affiliation and religious faith, numbers of siblings in a family, support from relatives and family ties contributes to quality of life of caregivers of persons living with sickle cell disease and as such these sociodemographic profiles should importantly considered when trying to boost the quality of life level of caregivers of persons living with sickle cell disease. Furthermore, the joint significant of optimism, self-efficacy, resilience and hope on quality of life indicates the important of psychological capital on quality of life and psychological wellbeing of caregivers of person living sickle cell [45-59].

\section{Limitations of Study}

This study is a cross sectional study which was not under controlled environment, therefore caution must be taken in generalizing the results. Also, this study was restricted to caregiver in Lagos state setting. Future studies should therefore ensure that it cut across wider settings.

\section{References}

1. Amr MA, Amin TT, Al Omair OA (2011) Health related quality of life among adolescents with sickle cell disease in Saudi Arabia. Pan Afr Med J 8: 10. 


\section{Psychology and Behavioral Science International Journal}

2. Bhagat VM, Baviskar SR, Mudey AB, Goyal RC (2014) Poor health related quality of life among patients of sickle cell disease. Indian J Palliat Care 20(2): 107-111.

3. Pereira SA, Brener S, Cardoso CS, Proietti AB (2013) Sickle cell disease: quality of life in patients with hemoglobin SS and SC disorders. Rev Bras Hematol Hemoter 35(5): 325-331.

4. Minh HV, Huong DL, Giang KB (2008) Self-reported chronic diseases and associated sociodemographic status and lifestyle risk factors among rural Vietnamese adults. Scand J public health 36(6): 629-634.

5. Barakat, Patterson, Lauren, Carlton (2008) Quality of life among adolescents with sickle cell disease: mediation of pain by internalizing symptoms and parenting stress. Health Qual Life Outcomes 6: 60.

6. Ayinmode $\mathrm{T}$ (2011) Children with sickle cell disease who are experiencing psychosocial problems concurrently with their mothers; A Nigerian study. African journal of psychiatry 14(5): 392-401.

7. Bentsen SB, Wentzel Larsen T, Henriksen AH, Rokne B, Wahl AK (2010) Self-efficacy as a predictor of improvement in health status and overall quality of life in pulmonary rehabilitation--an exploratory study. Patient Educ Couns 81(1): 5-13.

8. Cramm JM, Strating MM, Roebroeck ME, Nieboer AP (2013) The importance of general self-efficacy for the quality of life adolescents with chronic conditions. Soc Indic Res 113(1): 551-561.

9. Trude Haugland, Astrid Klopstad Wahl, Dag Hofoss, Holli A DeVon (2016) Association between general self-efficacy, social support, cancer-related stress and physical health-related quality of life: a path model study in patients with neuroendocrine tumors. Health and Quality of Life Outcomes 14:11.

10. Mazanec SR, Daly BJ, Douglas SL, Lipson AR (2010) The relationship between optimism and quality of life in newly diagnosed cancer patients. Cancer Nurs 33(3): 235-243.

11. Conversano C, Rotondo A, Lensi E, Della Vista O, Arpone F, et al. (2010) Optimism and its impact on mental and physical wellbeing. Clin Pract Epidemiol Ment Health 6: 25-29.

12. Vilhena E, Pais Ribeiro J, Silva I, Pedro L, Meneses RF, et al. (2014) Optimism on quality of life in Portuguese chronic patients: moderator/ mediator? Rev Assoc Med Bras 60(4): 373-380.

13. Lam, Fielding (2012) Living with cancer: prevalence of shame, anger, worry, and problems in daily activities and social life. Acta Derm Venerol 92: 299-303.

14. Jones (2012) The present application and the progress of cognitivebehavioural therapy. Psychiatr Pol 40(2): 279-290.

15. Jafari, Najafi, Sohrabi, Dehshiri, Soleymani, et al. (2010) Life satisfaction, spirituality, well-being and hope in cancer patients. Procedia-social and behavioral sciences 5: 1362-1366.

16. Szramka-Pawlak B, Hornowska E, Walkowiak H, Zaba R (2013) Hope as a psychological factor affecting quality of life in patients with psoriasis. Appl res Qual life (2014) 9: 273-283.

17. Duggleby WD, Swindle J, Peacock S, Ghosh S (2011) A mixed methods study of hope, transitions and quality of life in family caregivers of persons with alzheimer's disease. BMC Geriatr 11:88.

18. Talepasand S, Pooragha F, Kazemi M (2013) Resiliency and quality of life in patients with cancer: moderating role of duration of awareness of cancer. Iran J Cancer Prev 6(4): 222-226.

19. Malik S, Afzal N (2015) Predictors of quality of life and resilience among outpatients with heart disease. Iran Journal of Public Health 11: $114-120$.

20. Luthans F, Youssef CM, Avolio BJ (2007) Psychological capital. New York: Oxford University Press, New York.

21. Gladis MM, Gosch EA, Dishuk NM, Crits Christoph P (1999) Quality of life: Expanding the scope of clinical significance. J Consult Clin Psychol 67(3): 320-331.

22. Jain, Singh (2014) Reintroducing Parental Psychological Control. In Intrusive parenting: How psychological control affects children and adolescents. Washington, DC: American Psychological Association, USA, P: 3-13.

23. Gillespie BM, Chaboyer W, Wallis M (2007) Development of a theoretically derived model of resilience through concept analysis. Contemp Nurse 25(1-2): 124-135.

24. Snyder, Harris, Anderson, Holleran, Irving, et al. (1991) The will and the ways: Development and validation of an individual differences measure of hope. J pers and soc psychol 60(4): 570-585.

25. Nicholson M (1993) The development of resilience scale: component of psychological capital.

26. Farzaneh, Mitra, Mansoreh (2017) Health problems and coping with them-from denial to positive emotions. In: Ogińska-Bulik N, Miniszewska J (Eds.), Health in the human life cycle [Polish], Publishing of University of Lodz, Lodz, Ploand.

27. Albert, Mania, Bogetto, Chiorle, Matain-Cols (2010) The relationship between quality of life and psychological capital in sickle cell patients. African journal of psychiatry 21(3): 111-121.

28. Avolio BJ, Luthans F (2006) The high impact leader: Moments matter for accelerating authentic leadership development. New York: McGraw-Hill, New York.

29. Bandura A (1997) Self-efficacy and health behaviour. In: Baum, Wienman, McManus (Eds.), Cambridge handbook of psychology, health and medicine, Cambridge University Press, UK, pp: 160-162.

30. Scheier MF, Carver CS (2015) Optimism, coping, and health: Assessment and implications of generalized outcome expectancies. Health Psychol 4(3): 219-247.

31. Bryant FB, Cvengros JA (2004) Distinguishing hope and optimism. Journal of Social and Clinical Psychology 23: 273-302.

32. Cicchetti D, Toth SL (1998) The Development of Depression in Children and Adolescents. Am Psychol 53(2): 221-241.

33. Duggleby, Williams, Ghosh, Moquin, Ploeg, et al. (2016) Is general self-efficacy a universal construct? Psychometric findings from 25 countries. European Journal of Psychological Assessment 18: 242-251.

34. Fredrickson BL (2001) The role of positive emotions in positive psychology: The broaden-and- build theory of positive emotions. Am Psychol 56(3): 218-226.

35. Hobfoll, Stevan E (2002) Social and psychological resources and adaptation. Review of General Psychology 6(4): 307-324.

36. Thomas A Wright (2005) Positive organizational behavior: an idea whose time has truly come. Journal of Organizational Behavior 24(4): 437-442.

37. Utne I, Miaskowski C, Paul SM, Rustøen T (2013) Association between hope and burden reported by family caregivers of patients with advanced cancer. Journal of public health 21(9): 2527-2535.

38. Javalkar, Rak, Philips, Haberman, Ferris, et al. (2017) Self-efficacy as a resource factor in stress appraisal. In: R Schwarzer (Edt.), Self-efficacy: Thought control of action, Washington, DC: Hemisphere, USA, pp: 195216.

39. Law KS, Wong C, Mobley WH (1998) Toward a taxonomy of multidimensional constructs. Academy of Management 23(4): 741755 .

40. Luthans F (1990) Positive workplaces. In: Snyder CR, Lopez SJ (Eds.), Handbook of positive psychology ( $2^{\text {nd }}$ edn.), New York: Oxford University Press, UK. 


\section{Psychology and Behavioral Science International Journal}

41. Luthans F, Avey JB, Avolio BJ, Norman S, Combs G (2006) Psychological capital development: Toward a micro-intervention. Journal of Organizational Behavior 27(3): 387-393.

42. Luthans F, Youssef CM (2007) Emerging positive organizational behavior. Journal of Management 33: 321-349.

43. Manne, Myers Virtue, Kashy, Ozga, Kissane, et al. (2015) Quality of life therapy: Applying a life satisfaction approach to positive psychology and cognitive therapy. Hoboken, NJ: John Wiley \& Sons.

44. Maslow AJ (1954) Motivation and personality. New York: Harper \& Row, New York.

45. Cross MJ, March LM, Lapsley HM, Byrne E, Brooks PM (2011) Patient self-efficacy and health locus of control: Relationships with health status and arthritis-related expenditure. Rheumatology (Oxford) 45(1): 92-96.

46. Myaskovsky, Posluszny, Schulz, Di Martini, Switzer, et al. (2012) Psychological aspects of cardiothoracic: stress coping strategies and stigmatization. Postep Derm Alergol 29: 14-18.

47. Netuveli G, Blane D (2008) Quality of life in older ages. Br Med Bull 85: 113-126.

48. Nguyen, Trang, Nguyen (2012) Psychological capital, quality of work life and quality of life of marketers. Journal of Macromarketing 32(1) 11-15.

49. Pearce, Signer, Prigerson (2006) The impact of cancer on the quality of life and psychological characteristics of persons suffering from cancer Coll Antropol 35 (Suppl. 2): 81-85.

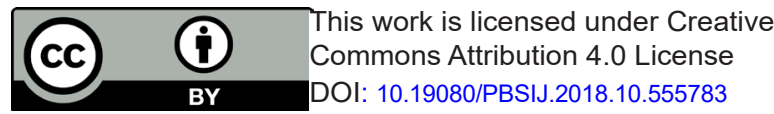

50. Pinquart, Duberstein (2007) Disease coping and quality of life in lungs cancer patients [Polish]. Przegl Cancer 90: 267-272.

51. Rayyani, Malekyan, Forouzi, Razban (2014) Perceived self-efficacy in health behavior research: Conceptualisation, measurement and correlates. Psychology \& Health 15: 51-69.

52. Shabnambidarian, Parivashjafari, Nadergholighourchain (2015) The metatheory of resilience and resiliency. Journal of Clinical Psychology 58(3): 307-321.

53. Sirgy S (1986) Measuring the Quality of Life. From Theory to Practice. For skningscentrets for lag, Copenhagen, Danish.

54. Snyder CR (2000) Handbook of hope. San Diego: Academic Press, USA.

55. Snyder CR (2002) Hope theory: Rainbows in the mind. Psychological Inquiry 13(4): 249-276.

56. Snyder CR, Lopez S (2002) Handbook of positive psychology. Oxford, UK: Oxford University Press, USA.

57. Ventegodt S, Merrick J, Andersen NJ (2003) Quality of life as medicine: a pilot syudy of patients with chronic illness and pain. ScientificWorldJournal 3: 520-532.

58. Wennman-Larsen, Tishelman (2002) Advanced home care for cancer patients at the end of life: a qualitative study of hopes and expectations of family caregivers. Scand J Caring Sci 16(3): 240-247.

59. Petersen C, Schmidt S, Power M, Bullinger M, DISABKIDS Group (2005) Development and pilot-testing of a health-related quality of life chronic generic module for children and adolescents with chronic health conditions: A European perspective. Qual Life Res 14(4): 1065-1077.

\section{Your next submission with Juniper Publishers will reach you the below assets}

- Quality Editorial service

- Swift Peer Review

- Reprints availability

- E-prints Service

- Manuscript Podcast for convenient understanding

- Global attainment for your research

- Manuscript accessibility in different formats ( Pdf, E-pub, Full Text, Audio)

- Unceasing customer service

Track the below URL for one-step submission

https://juniperpublishers.com/online-submission.php 